\title{
EXPERIMENTAL WORKS
}

UDC 581.1

https://doi.org/10.15407/ubj88.06.026

\section{PURIFICATION AND PROPERTIES OF LIPOXYGENASE FROM WHEAT SEEDLINGS INFECTED BY Fusarium graminearum AND TREATED BY SALICYLIC ACID}

O. O. MOLODCHENKOVA ${ }^{1}$, V. G. ADAMOVSKAYA ${ }^{1}$, L. Y. CISELSKAYA ${ }^{1}$, L. Ya. BEZKROVNAYA $A^{1}$, T. V. KARTUZOVA ${ }^{1}$, V. B. IABLONSKA ${ }^{2}$

\author{
${ }^{1}$ Plant Breeding and Genetics Institute-National Center of Seed \\ and Cultivar Investigation, Ukraine; \\ e-mail: olgamolod@ukr.net; \\ ${ }^{2}$ Odessa National Medical University, Ukraine; \\ e-mail:93vi_63@mail.ru
}

Lipoxygenase from wheat seedlings in normal conditions, infected by Fusarium graminearum and treated by salicylic acid was isolated. The isolated enzyme was purified by the methods of salting-out (60\% ammonium sulphate), dialysis, gel-filtration and ion-exchange chromatography. Specific activity of the purified enzyme was 8.0-12.5 $\Delta E_{234}$ mg of protein, degree of purification - 11.6-15.3 times. The enzyme yield was 18.3-27.9\%. Molecular mass of lipoxygenase is $90 \mathrm{kDa}$, amino acid composition is distinguished by a high content of glutamic acid, proline,valine, isoleucine, leucine and low level of histidine, tyrosine, phenylalanine, threonine, tryptophan, cystein. Research of lipoxygenase substrate dependence indicated that the enzyme catalysed with the maximum velocity of the reaction of arachidonic acid oxidation at a substrate concentration of $4.5 \mathrm{mM}$ at $\mathrm{pH} 7.2$, the reaction of linoleic acid oxidation at a substrate concentration of $4.5 \mathrm{mM}$ at pH 7.2 and the reaction of linolenic acid oxidation at a substrate concentration of $9.0 \mathrm{mM}$ at $\mathrm{pH}$ 8.0. The change of wheat lipoxygenase activity depending on genotype resistance to Fusarium graminearum and millieu of germination was shown. One of the manifestations of the protective effect of salicylic acid is its ability to induce changes of lipoxygenase activity.

Key words: Triticum aestivum L., lipoxygenase, purification and properties, fusariosis, salicylic acid.

I $\mathrm{t}$ is known that enzymes participating in lipid metabolism may take an active part in forming defense responses of plants. Activation of lipases and increase of free fatty acids, which can further be metabolized through lipoxygenase pathway, occur as a results of interation between elicitors and receptors of plasmalemma. Lipoxygenase (EC 1.13.11.12, LOG) is one of the key enzymes of lipoxygenase metabolism that results in formation of compounds, being toxic for most pathogens, as well as phytodienic and jasmonic acids. Interest to the given enzyme is also caused by the fact that catalyzing the process of peroxide oxidation of unsaturated fatty acids, lipoxygenase can affect the composition of membrane lipids and functions of plant cell biomembranes $[4,5]$.
The process of pathogens identification in plants proceeds with the help of signal systems which determine the response of cells to various chemicall and physical effects. The number of compounds, performing the function of the signal system mediators, constantly grows. Salicylic acid belongs to such compounds. It takes part in activation of the whole complex of protective responses of plants that are important for forming resistance to biotic and abiotic stresses [6].

In spite of broad distribution and important functions of lipoxygenase in the plant and animal organisms, the structure, activation mechanisms and role of this enzyme in forming the mechanisms of plants resistance, wheat in particular, is not sufficiently studied. Thus, the isolation and investigation 
of lipoxygenase from the wheat plants distinguished by the level of resistance to fusariosis, one of the most harmful diseases, and grown on the media containing pathogenic infection and solution of salicylic acid, the inducer of plant protective reactions, is urgent and important for finding out the enzyme structure and its role in defense mechanisms of the wheat plants. In this connection the objective of this study consisted in performing the isolation, purification and characterization of properties of lipoxygenase from the wheat seedlings grown in normal conditions, infected by the fusariosis agents and treated by the inducer of resistance (salicylic acis (SA)).

\section{Materials and Methods}

Lipoxygenase was isolated from the overground part of 4-day seedlings of the wheat (Triticum aestivum L.) genotypes, distinguished by resistance to fusariosis agents (line Erythrospermum 84/06 - resistant to fusariosis; variety Odeskaya polukarlikovaya (Odessa halh-dwarf) - susceptible to fusariosis. A highly pathogenic strain K-90 Fusarium graminearum served as the infection agent. Colonies of Fusarium graminearum K-90 from the collection of strains of the Department of Phytopathology and Entomology of Plant Breeding and Genetics Institute - National Center of Seed and Cultivar Investigation were grown on the potato agar. To obtain filtrate the pore suspension was introduced into the liquid potato medium and cultivated for 10 days at $24{ }^{\circ} \mathrm{C}$. The undamaged wheat cariopses grown on filter paper in thermostate at $25{ }^{\circ} \mathrm{C}$ and relative air humidity $60 \%$ during 4 days were used in the experiments. The infection of plants with the pathogen was conducted, when growing the seedlings in the medium which contained $1 \times 10^{5}$ conidia/ml of the pathogenic strain K-90 Fusarium graminearum. Treatment of plants with salicylic acid was conducted when growing the plants for 4 days on the filter paper wetted with $2 \mathrm{mM}$ solution of salicylic acid. Under mutual action of the pathogen and salicylic acid the grains moistened during a night in the $0.1 \mathrm{mM}$ solution of salicylic acid were set out on suspension with the pathogen. The exposure being over, the prepared overground part of sprouts was frozen at $-70{ }^{\circ} \mathrm{C}$, liophylically dried and ground.

The stages of isolation and purification of lipoxygenase from the overground part of seedlings consisted of the extraction by $0.05 \mathrm{M}$ phosphate buffer, $\mathrm{pH} 7.2$, salting out by $60 \%$ ammonium sulfate, dialysis, Sephadex G-100 gel-filtration (Pharmacia,
Sweden) and Sepharose CL-6B ion-exchange chromatography (Pharmacia, Sweden). Column chromatography of lipoxygenase was performed with the help of the equipment of the firm LKB (Sweden), using a low-temperature cabinet (Combicoldrac II), peristaltic pump (Microperpex), ultraviolet detector with a flow-type cuvette (Uvicord S), collector of fractions (Ultrorac II), columns $2.6 \times 60 \mathrm{~cm}$, $1.6 \times 95 \mathrm{~cm}$ (for G-100), $1.6 \times 70 \mathrm{~cm}$ (for DEAESepharose CL-6B) at $4{ }^{\circ} \mathrm{C}$. Treatment of the Sephadex G-100, ion exchanger DEAE-Sepharose CL-6B was performed following standard methods [7, 8]. The enzyme activity was determined spectrophotometrically by the reaction of fermentative formation of fatty acid hydroperoxides, recorded at $234 \mathrm{~nm}$. A mixture of fatty acids isolated from walnut kernels was used as a substrate. The content of linoleic acid in the mixture was $67 \%$. Concentration of the acid in the mixture was $2.8 \mathrm{mM}$. The extinction change by 0.01 for 1 min was taken as the unit of lipoxygenase activity. The total protein content in the extract was determined by the Lowry method [10]. The isolated lipoxygenase was determined by the method of analytical electrophoresis in PAAG in the alkali buffer system at $\mathrm{pH} 8.3$, using a specific oxidation reaction of linoleic acid in the presence of starch and potassium iodide [11, 12]. To reveal the zone of lipoxygenase location in gels we used the method by Heil with co-authors [13], based on formation of stained iodine-starch complex in the presence of potassium iodide and linoleic acid hydroperoxides. This in mind soluble starch was introduced before polymerization in gel to concentration of $1 \%$; electrophoresis being finished, gel was incubated for 30-min in $0.5-1.0 \%$ solution of sodium salt of linoleic acid. Then the gel, thoroughly washed in distilled water, was placed into mixture-developer which consisted of $100 \mathrm{ml}$ of $7 \%$ acetic acid and $5 \mathrm{ml}$ of freshly prepared saturated solution of KI. The appearance of brown-violet stripes on the yellow background of the gel evidenced for availability of lipoxygenase isoforms.

Amino acid analysis of lipoxygenase was performed by automatic analyzer of amino acids Hitachi-835 (Japan). The samples were hydrolyzed in $6 \mathrm{M}$ hydrochloric acid at $105^{\circ} \mathrm{C}$ in hermetically sealed flasks during $24 \mathrm{~h}$. After hydrolysis the samples were stewed in the rotor evaporator Rodatest (Hungary), and the precipitate was dissolved in $0.02 \mathrm{M}$ hydrochloric acid.

Molecular mass of lipoxygenase was determined using gel-filtration [7] on a column $1.6 \times 95 \mathrm{~cm}$ 
with Sephadex G-100 (Pharmacia, Sweden), balanced by $0.05 \mathrm{M}$ phosphate buffer $\mathrm{pH} 7.2$ at the flow velocity $7.5 \mathrm{ml} / \mathrm{cm}^{2} \cdot h$. Proteins-markers produced by Serva (Germany) were used to plot the calibration graph.

Statistical processing of the investigation results was made using the pack of programs Analysis of the Data of Electron Tables Microsoft Excel, image analysis programs Imagel, AnaIS. The experiments were performed in triple biological and analytical repetitions. Mean values and their standard errors are presented in Fig. 5 and Table 2, differences between the experiment variants, distinquished by genotypes resistance to parthogen, were considered reliable at the significance level $P<0.05$ by the Student criterion.

\section{Results and Discussion}

Lipoxygenase was extracted from the seedlings tissues by $0.05 \mathrm{M}$ phosphate buffer, $\mathrm{pH} 7.2$ at $4{ }^{\circ} \mathrm{C}$ during $30 \mathrm{~min}$ at the ratio mass:volume $1: 10$. Homogenate was centrifuged during $20 \mathrm{~min}$ at $6000 \mathrm{~g}$ $\left(4{ }^{\circ} \mathrm{C}\right)$, using a supernatant for further purification. Our purification plan includes 4 stages.

Stage 1. Salting out. Supernatant was salted out by ammonium sulphate at saturation $60 \%(162.5 \mathrm{~g} / \mathrm{l})$. Sediment was separated by centrifugation during $20 \mathrm{~min}$ at $6000 \mathrm{~g}\left(4^{\circ} \mathrm{C}\right)$.

Stage 2. Dialysis. The sediment was dissolved by $0.05 \mathrm{M}$ phosphate buffer at $\mathrm{pH} 7.2$, and put to dialysis against 20 -fold volume of distilled water during night at $4{ }^{\circ} \mathrm{C}$, using dialysis membranes (Regenerated cellulose tubular membrane, Fisher Scientific, USA) with pore diameter of 12-14 kDa. After dialysis the enzyme solution was centrifuged for $20 \mathrm{~min}$ at $6000 \mathrm{~g}\left(4^{\circ} \mathrm{C}\right)$, the enzyme activity and protein content were determined in supernatant. The latter was used for further purification.

Stage 3. Gel-filtration. The enzyme solution was lyophilically dried, dissolved in $0.05 \mathrm{M}$ phosphate buffer at $\mathrm{pH} 7.2$, and gel-filtration was performed on the column $(2.6 \times 60 \mathrm{~cm})$ with Sephadex G-100 in the same buffer with velocity $7.5 \mathrm{ml} / \mathrm{cm}^{2} \cdot \mathrm{h}$, gathering fractions of $5 \mathrm{ml}$. The fractions with maximum enzyme activity were united and used for further purification.

Stage 4. Ion-exchange chromatography. The enzyme solution was applied to the column $(1.6 \times 70 \mathrm{~cm})$ with DEAE-Sepharose CL-6B, balanced with the above buffer solution. Lipoxygenase was eluted with linear gradient $\mathrm{NaCl}$ from 0.01 to
$0.5 \mathrm{M}$ with flow velocity $3 \mathrm{ml} / \mathrm{cm}^{2} \cdot h$, gathering fractions of $5 \mathrm{ml}$. The fractions with maximum enzyme activity were extracted.

After the extraction, salting out by ammonium sulfate with following dialysis the specific activity of lipoxygenase from the wheat seedlings was 0.288 0.530 exp.un $/ \mathrm{min} / \mathrm{mg}$ of protein.

Sephadex G-100 gel-filtration has helped to purify lipoxygenase from considerable amount of low-molecular impurities of non-protein nature. Lipoxygenase yield from the wheat seedlings in the region of proteins with molecular mass of $97 \mathrm{kDa}$, $67 \mathrm{kDa}$, and $20 \mathrm{kDa}$ (Fig. 1) had 3 peaks. After gelfiltration the enzyme specific activity increased 1.53-2.53 times. Fractions obtained after gel-filtration and characterized by the enzyme maximum activity (peaks 1-2), were lyophilized and applied to the column with DEAE-Sepharose CL-6B. Under DEAE-Sepharose CL-6B chromatography the

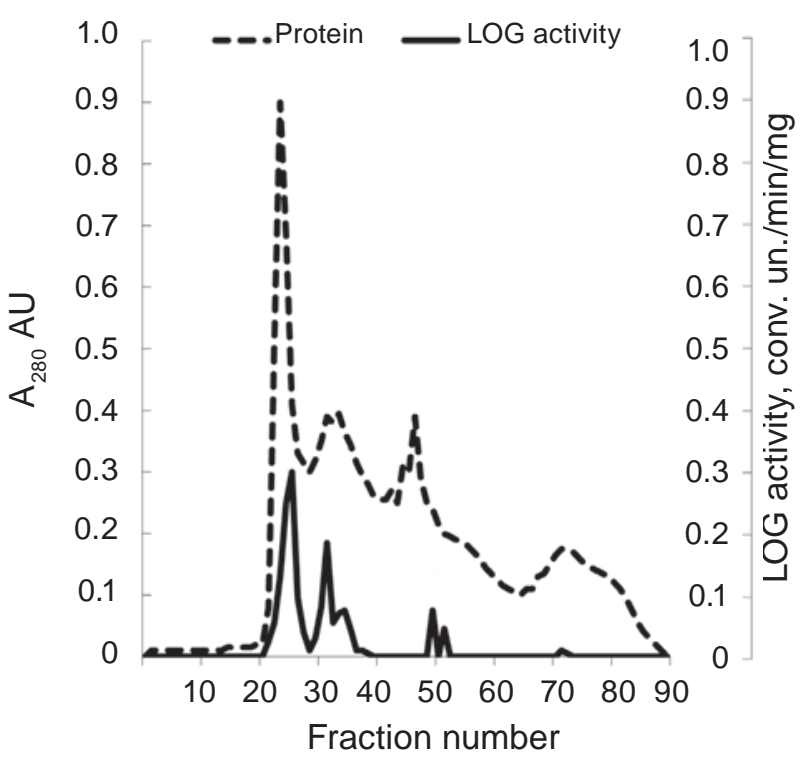

Fig. 1. Evolution profile of lipoxygenase from the seedlings of wheat of Erythrospermum 84/06 line on Sephadex G-100. Column $2.6 \times 60 \mathrm{~cm}$, velocity $7.5 \mathrm{ml} / \mathrm{cm}^{2} \cdot h$, fraction volume $-5 \mathrm{ml}$, elution by $0.05 \mathrm{M}$ phosphate buffer $\mathrm{pH}$ 7.2. Protein is applied$463.3 \mathrm{mg} .1-3$ - LOG fractions. Markers of molecular mass: fractions 17-20 - ferritin (330 kDa); fractions 22-29 - phosphorylase B (97 kDa); fractions 29-34 - bovine serum albumin (67 kDa); fractions 35-40 - albumin (45 kDa); fractions 42-43 - carboanhydrase (30 $\mathrm{kDa})$; fractions $45-50$ - soya inhibitor of trypsine (20 kDa); fractions 55-56-L-lactalbumin $(14.4 \mathrm{kDa})$ 


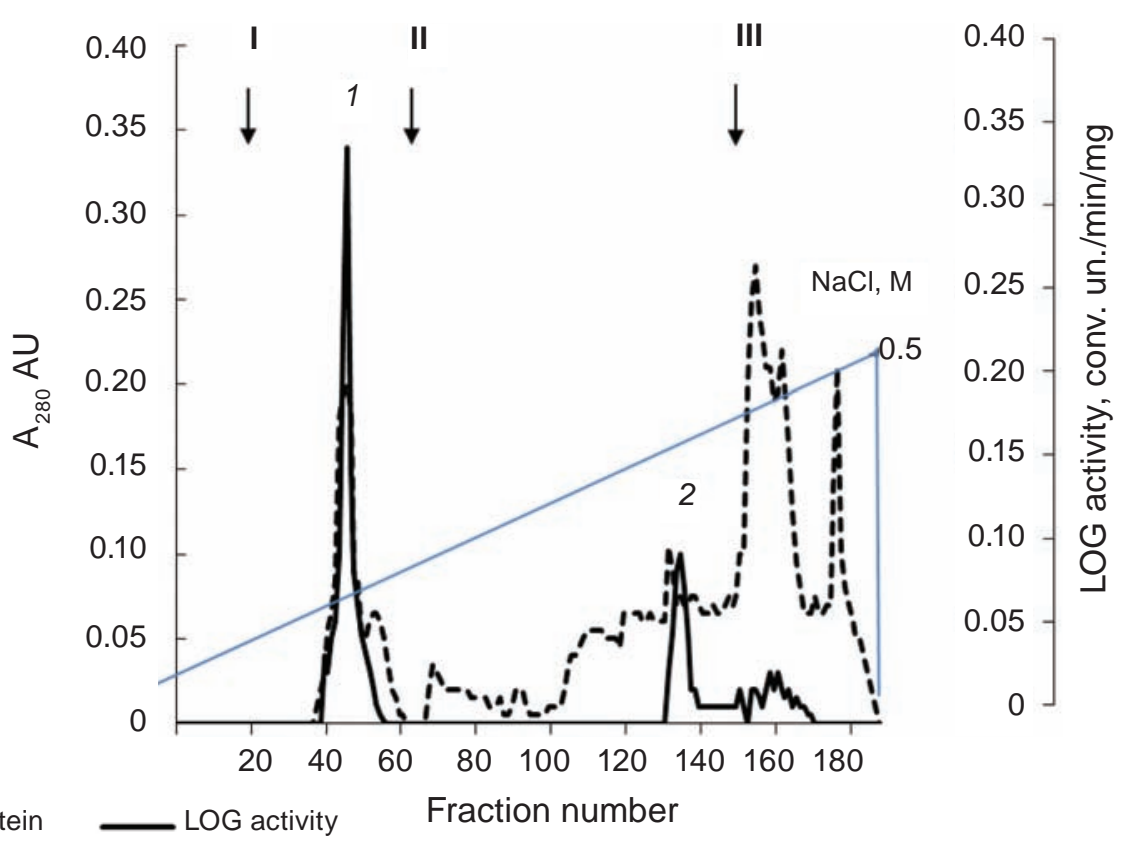

Fig. 2. Evolution profile of lipoxygenase from the seedlings of wheat Erythrospermum 84/06 line on DEAESepharose CL-6B. Column $1.6 \times 70 \mathrm{~cm}$, velocity $2 \mathrm{ml} / \mathrm{cm}^{2} \cdot \mathrm{h}$, fraction volume $-5 \mathrm{ml}$, elution by $0.05 \mathrm{M}$ phosphate buffer $p H$ 7.2. Protein is applied - $154.5 \mathrm{mg}$. 1-2 - LOG fractions. I-0.05 M phosphate buffer $\mathrm{pH} 7.2+$ $0.05 \mathrm{M} \mathrm{NaCl}$; II - $0.05 \mathrm{M}$ phosphate buffer $\mathrm{pH} 7.2+0.05-0.2 \mathrm{M} \mathrm{NaCl}$; III - $0.05 \mathrm{M}$ phosphate buffer pH 7.2 $+0.2-0.5 \mathrm{M} \mathrm{NaCl}$

lipoxygenase activity was found in the form of two peaks (Fig. 2). The first peak appeared at $\mathrm{NaCl}$ concentration equal to $0.05 \mathrm{M}$, while the second peak appeared under the gradient 0.05-0.2 $\mathrm{M} \mathrm{NaCl}$. Maximum activity of the enzyme was found in the first peak. The material, which activity was 18.3-27.9 times higher compared with lipoxygenase activity after salting out, was obtained as a result of using the DEAE-Sepharose CL-6B chromatography.

As a result of using Sephadex G-100 gel filtration and DEAE-Sepharose CL-6B ion exchange chromatography the yield of lipoxygenase preparation from the control samples was $37.7 \%$ with purification coefficient 27.7; from seedlings treated with SA $-42.7 \%$ with purification coefficient 18.32 ; from infected speedlings $56.6 \%$ with purification coefficient $27.95 \%$ and from infected seedlings after preliminary treatment of grain by SA $48.8 \%$ with purification coefficient 27 (Table 1). Molecular mass of isolated enzymes, determined by the method of Sephadex G-100 gel-filtration, was 90 kDa (Fig. 3). Results of electrophoretic analysis of isolated enzymes are presented on Fig. 4.

When determining enzyme activity in conditions of the incubation medium $\mathrm{pH}$ 4.5-10.0, it was found that its optimum for lipoxygenase of all the studied samples is within 7.8-8.0.

The investigation of substrate dependence of lipoxygenase activity in the peroxidation reaction of linoleic, linolenic and arachidonic acids has shown the effect of more intensive oxidation of arachidonic acid under the substrate concentration $4.5 \mathrm{mM}$ with $\mathrm{pH}$ 7.2, linoleic acid under substrate concentration $4.5 \mathrm{mM}$ with $\mathrm{pH} 7.2$ and linolenic acid under substrate concentration $9.0 \mathrm{mM}$ with $\mathrm{pH} 8.0$ (Table 2).

Investigation of amino acid composition of lipoxygenase isolated from wheat seedlings allowed revealing in the enxyme composition high, compared with other amino acids, amount of glutamic acid ( $16.7 \%$ of the total amount of amino acids), aspartic acid (7.5\%), proline (9.8\%), valine $(6.9 \%)$, isoleucine $(5.9 \%)$, leucine $(9.2 \%)$ and low content of histidine $(1.2 \%)$, phenylalanine $(3.7 \%)$, threonine $(3.1 \%)$, tryptophan $(3.7 \%)$, cystein $(3.5 \%)$, that agrees with literature data [14]. The total amount of acid amino acids in lipoxygenase composition was $22.86 \%$, and that of basic amino acids $-7.71 \%$.

One of possible functions of lipoxygenase is its participation in formation of plant protection reactions against pathogenesis. To confirm this suppo- 


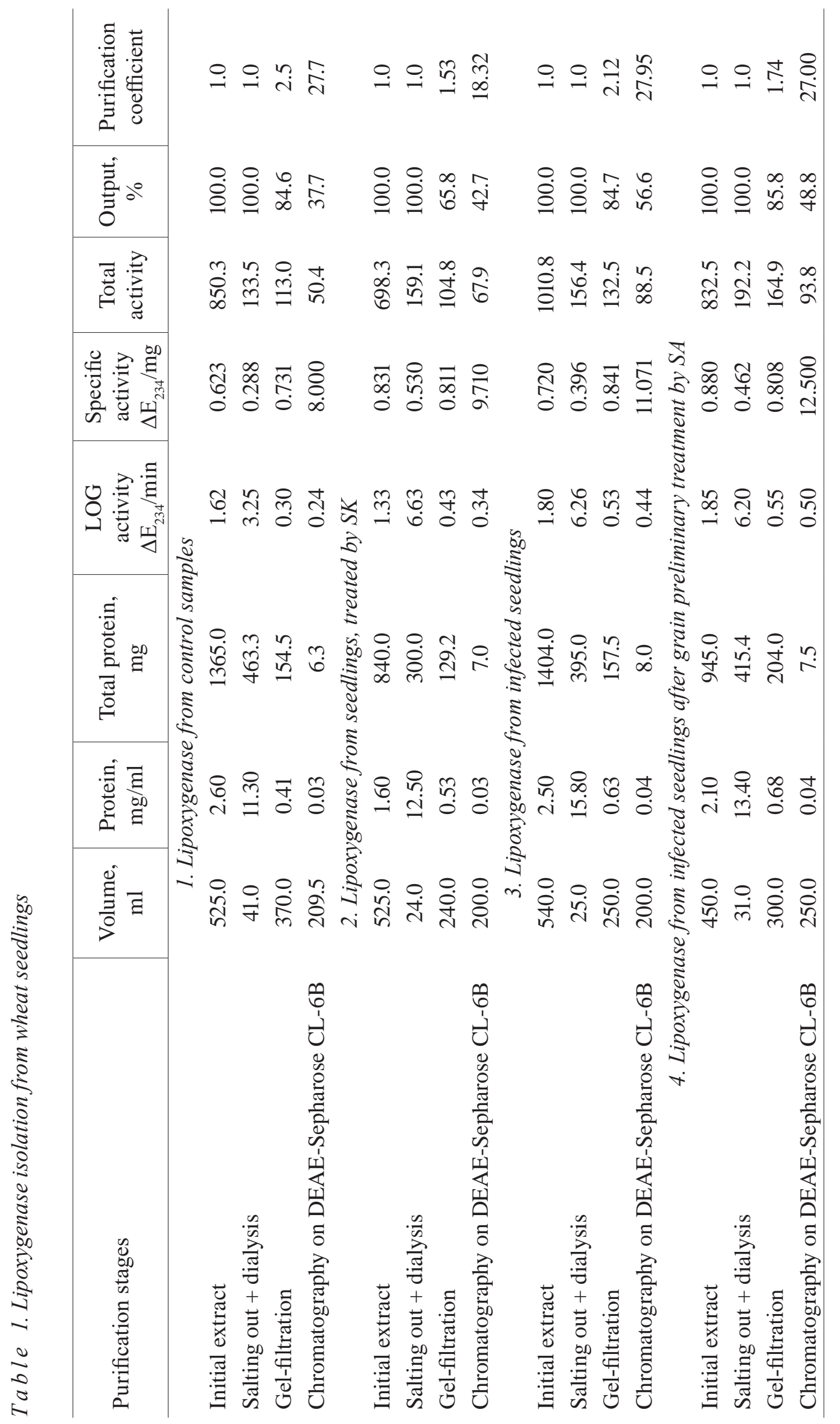




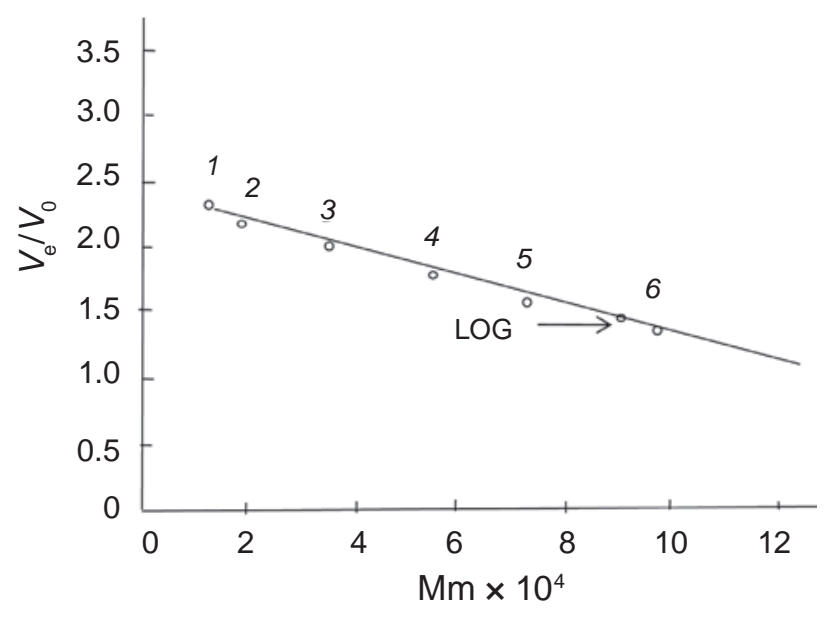

Fig. 3. Determination of molecular mass of lipoxygenase by the method of Sephadex G-100 gel filtration: 1-L-lactalbumin (14.4 kDa); 2-soya of trypsin inhibitors activity $(20 \mathrm{kDa}) ; 3$ - carboanhydrase (30 kDa); 4 - albumin (45 kDa); 5 - Bovine serum albumin (67 kDa); 6 - phosphorylase $B(97 \mathrm{kDa}$ ), $L O G$ - lipoxygenase, $V_{e}-$ volume of evolution, $V_{0}-$ free column volume, $\mathrm{Mm}$ - molecular mass

sition we have studied lipoxygenase activity in the control plants, those infected by Fusarium graminearum, treated by SA in wheat genotypes distinguished by the level of resistance to fusariosis agents. The conducted studies have shown that the 2.3- and 2.6fold increase of enzyme activity compared with control, respectively, was observed in the resistant wheat genotype under the effect of pathogen and SA. The enzyme activity of a susceptible genome did not practically differ from the control plants under seedlings infection by Fusarium graminearum and inconsiderably but reliably increased at $P \leq 0.05$ under the effect of SA (Fig. 5). The enzyme activity in the stable genotype seedlings, grown on the pathogen suspension after preliminary grain treatment with SA, reliably increased in respect of the control, but the enzyme activation level was lower than that in the infected seedlings treated with SA. Lipoxygenase activity in the seedlings of susceptible genotype under joint action of pathogene and SA, as well as in the infected plants treated with SA, increased inconsiderably but reliably at $P \leq 0.05$ in respect of the control and infected seedlings. A similar response to the joint action of fusariosis infection and SA was established by the change of trypsin activity inhibitors [15].

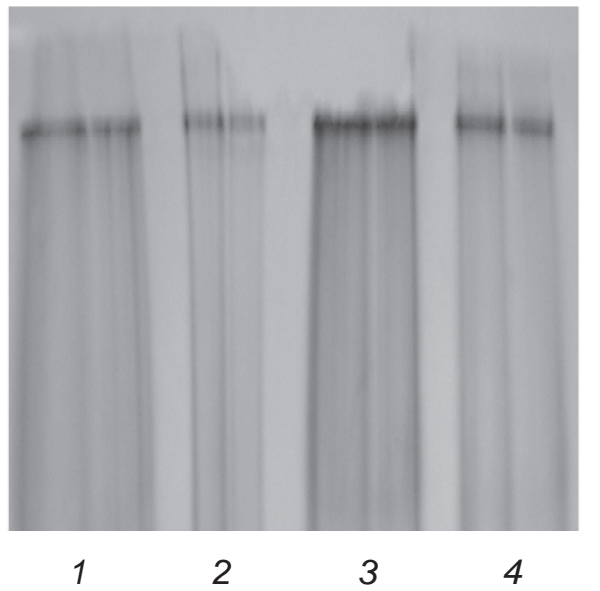

Fig. 4. Electrophoresis in 7\% PAAG with 1\% starch of lipoxygenases isolated ftom the overground part of wheat seedlings under different germination conditions: 1 - control (Erythrospermum line 84/06); 2 - SA (Erythrospermum line 84/06); 3 - Fusarium graminearum (Erythrospermum line 84/06); 4-SA + Fusarium graminearum (Erythrospermum line 84/06)

Such a response of the wheat plants to the action of salicylic acid and fusariosis infection evidences that the joint action of these factors causes complex interaction directed to preservation and increase of plants resistance to the given pathogen. The wheat plants response to fusariosis agent infection and the effect of salicylic acid is regulated by the interaction of separate components of biochemical defense system. The regulating effect of biochemical plants is determined by the effect factor nature, mobilization velocity of the defense mechanisms which have their display peculiarities depending on the level of the genotype stability. The results obtained evidence for lipoxygenase involvement in the regulation of cell metabolism of the wheat plants under the effect of fusariosis infection and salicylic acid.

Thus, using the methods of salting out, gelfiltration and ion exchange chromatography we have isolated, purified and studied some biochemical properties of lipoxygenase from the wheat seedlings infected by fusariosis agents and affected by salicylic acid. The obtained results on the change of activity of the enzyme infected by Fusarium graminearun and affected by salicylic acid evidence for lipoxygenase and SA participation in the defence responses and formation of the wheat plants resistan- 
Table 2. Dependence of lipoxygenase activity on substrate concentration and $\mathrm{pH}$

\begin{tabular}{|c|c|}
\hline Substrate & $\begin{array}{c}\text { Lypoxygenase activity, } \\
\qquad \Delta \mathrm{E}_{234} / \mathrm{min}\end{array}$ \\
\hline \multicolumn{2}{|c|}{ Linoleic acid } \\
\hline 4.5 mM, pH 7.0 & $0.092 \pm 0.0003$ \\
\hline 9.0 mM, pH 7.0 & $0.092 \pm 0.0005$ \\
\hline 4.5 mM, pH 7.2 & $0.100 \pm 0.0003$ \\
\hline 9.0 mM, pH 7.2 & $0.080 \pm 0.0004$ \\
\hline 4.5 mM, pH 8.0 & $0.077 \pm 0.0006$ \\
\hline 9.0 mM, pH 8.0 & $0.080 \pm 0.0028$ \\
\hline \multicolumn{2}{|c|}{ Linolenic acid } \\
\hline 4.5 mM, pH 7.0 & $0.080 \pm 0.0018$ \\
\hline 9.0 mM, pH 7.0 & $0.090 \pm 0.0008$ \\
\hline 4.5 mM, pH 7.2 & $0.095 \pm 0.0005$ \\
\hline 9.0 mM, pH 7.2 & $0.090 \pm 0.0004$ \\
\hline 4.5 mM, pH 8.0 & $0.100 \pm 0.0006$ \\
\hline 9.0 mM, pH 8.0 & $0.102 \pm 0.0011$ \\
\hline \multicolumn{2}{|c|}{ Arachidonic acid } \\
\hline 4.5 mM, pH 7.0 & $0.070 \pm 0.0003$ \\
\hline 9.0 mM, pH 7.0 & $0.100 \pm 0.0002$ \\
\hline 4.5 mM, pH 7.2 & $0.105 \pm 0.0004$ \\
\hline 9.0 mM, pH 7.2 & $0.092 \pm 0.0006$ \\
\hline 4.5 mM, pH 8.0 & $0.095 \pm 0.0008$ \\
\hline 9.0 mM, pH 8.0 & $0.095 \pm 0.0004$ \\
\hline
\end{tabular}

ce to fungal pathogens, fusariosis in particular. One of the manifestations of the defense action of SA is its capacity to induce changes of lipoxygenase activity. The data presented allow supposing that at various stages of plant development under the effect of fusariosis infection and SA the mechanisms and intensity of lipids peroxidation are apparently determined by molecular structure of lipoxygenase, that allows judging of adaptive peculiarities and regulation mechanisms of plants.

The results obtained may be of interest for the explanation and development of theoretical ideas of formation mechanisms of the defense responses of the wheat plants under fungal infection, role of lipoxygenase in these processes, structure and action mechanism of the given enzyme.

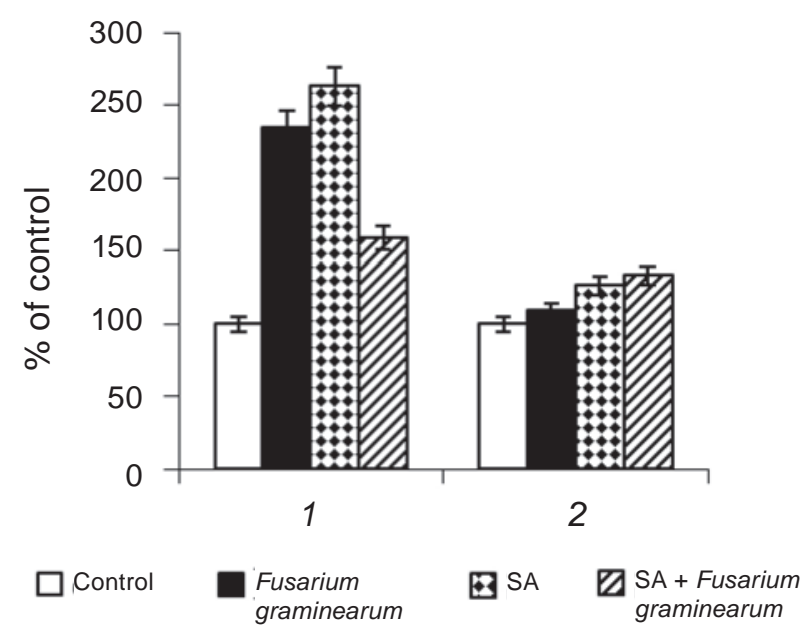

Fig. 5. Lypoxygenase activity in wheat seedlings in different growing conditions 1 - resistant genotype, 2 - susceptible genotype

\section{ОЧИСТКА ТА ВЛАСТИВОСТІ ЛІПОКСИГЕНАЗИ ІЗ ПРОРОСТКІВ ПШЕНИЦІ, ІНФІКОВАНИХ FUsarium graminearum ТА ОБРОБЛЕНИХ САЛІЦИЛОВОЮ КИСЛОТОЮ}
О. О. Молодченкова ${ }^{1}$, В. Г. Адамовська ${ }^{1}$, Л. Й. Цисельська ${ }^{1}$, Л. Я. Безкровна ${ }^{1}$, Т. В. Картузова ${ }^{1}$ В. Б. Яблонська ${ }^{2}$

${ }^{1}$ Селекційно-генетичний інститут-Національний центр насіннєзнавства та сортовивчення, Україна; e-mail: olgamolod@ukr.net;

${ }^{2}$ Одеський національний медичний університет, Україна; e-mail: 93vi_63@mail.ru

Ліпоксигеназа виділена із проростків пшениці, вирощених у нормальних умовах, інфікованих збудниками фузаріоза та оброблених саліциловою кислотою. Виділений ензим був очищений з використанням методів висолювання 60\%-им сульфатом амонію, діалізу, гель-фільтрації та іонообмінної хроматографії. Питома активність виділеної ліпоксигенази $8,0-12,5 \quad \Delta \mathrm{E}_{234} / \mathrm{M \Gamma}$ протеїну, ступінь очистки - 11,6-15,3 раза, вихід ензиму - 18,3-27,9\%. Молекулярна маса ліпоксигенази - 90 кДа, амінокислотний склад відрізнявся підвищеним вмістом глутамінової кислоти, проліну, валіну, ізолейцину, лейцину та низьким 
вмістом гістидину, тирозину, фенілаланіну, треоніну, триптофану, цистеїну. Під час дослідження субстратної залежності активності ліпоксигенази в реакції переокислення лінолевої, ліноленової та арахідонової кислот встановлено ефект інтенсивнішого окислення арахідонової кислоти при концентрації субстрату 4,5 мМ (pH 7,2), лінолевої кислоти при концентрації субстрату 4,5 мМ (pH 7,2) та ліноленової кислоти при концентрації субстрату 9,0 мМ (pH 8,0). Показана зміна активності ліпоксигенази, виділеної із проростків генотипів пшениці, які відрізняються за стійкістю до фузаріозу, залежно від стійкості генотипу до патогену та середовища пророщування. Одним із проявів захисної дії саліцилової кислоти є її здатність індукувати зміну активності ліпоксигенази.

К лючов і с сова: Triticum aestivum L., ліпоксигеназа, фузаріоз, саліцилова кислота.

\section{ОЧИСТКА И СВОЙСТВА ЛИПОКСИГЕНАЗЫ ИЗ ПРОРОСТКОВ ПШЕНИЦЫ, ИНФИЦИРОВАННЫХ Fusarium graminearum И ОБРАБОТАННЫХ САЛИЦИЛОВОЙ КИСЛОТОЙ}

О. О. Молодченкова ${ }^{1}$ В. Г. Адамовская ${ }^{1}$, Л. Й. Цисельская ${ }^{1}$, Л. Я. Безкровная ${ }^{1}$, Т. В. Картузова ${ }^{1}$ В. Б. Яблонская ${ }^{2}$

$$
\begin{gathered}
{ }^{1} \text { Селекционно-генетический институт- } \\
\text { Национальный центр семеноведения } \\
\text { и сортоизучения, Украина; } \\
\text { e-mail: olgamolod@ukr.net; } \\
{ }^{2} \text { Одесский национальный медицинский } \\
\text { университет, Украина; } \\
\text { e-mail: 93vi_63@mail.ru }
\end{gathered}
$$

Липоксигеназа выделена из проростков пшеницы, выращенных в нормальных условиях, инфицированных возбудителями фузариоза и обработанных салициловой кислотой. Выделенный энзим был очищен с использованием методов высаливания 60\%-ым сульфатом аммония, диализа, гель-фильтрации и ионообменной хроматографии. Удельная активность выделенной липоксигеназы - 8,0-12,5 $\Delta \mathrm{E}_{234}$ Мг протеина, степень очистки - в 11,6-15,3 раза, выход энзима $-18,3-27,9 \%$. Молекулярная масса липоксигеназы - 90 кДа, аминокислотный состав отличался повышенным содержанием глутаминовой кислоты, пролина, валина, изолейцина, лейцина и низким количеством гистидина, тирозина, фенилаланина, треонина, триптофана, цистеина. При исследовании субстратной зависимости активности липоксигеназы в реакции переокисления линолевой, линоленовой и арахидоновой кислот установлен эффект более интенсивного окисления арахидоновой кислоты при концентрации субстрата 4,5 мМ (pH 7,2), линолевой кислоты при концентрации субстрата 4,5 мМ (pH 7,2), и линоленовой кислоты при концентрации субстрата 9,0 мМ (pH 8,0). Показано изменение активности липоксигеназы, выделенной из проростков генотипов пшеницы, различающихся по устойчивости к фузариозу, в зависимости от устойчивости генотипа к патогену и среды проращивания. Одним из проявления защитного действия салициловой кислоты является ее способность индуцировать изменение активности липоксигеназы.

К лю юе в ы е с лов а: Triticum aestivum L., липоксигеназа, фузариоз, салициловая кислота.

\section{References}

1. Tarchevsky IA. Biogeneous stress in the plants. M.: Science, 2002. 294 p.

2. Iliynskaya LI, Vasyukova NI, Ozeretskovskaya OL. Biochemical aspects of induced plant resistance and susceptibility. M.: VINITI, 1991. P. 4-71.

3. Siedow JN. Plant lipoxygenase: structure and function. Annu Rev Plant Physiol Plant Mol Biol. 1991; 42: 145-158.

4. Porta H, Rocha-Sosa M. Plant lipoxygenases. Physiological and molecular features. Plant Physiol. 2002; 130(1): 15-21.

5. Rudolph M, Schlereth A, Körner M, Feussner K, Berndt E, Melzer M, Hornung E, Feussner I. The lipoxygenase-dependent oxygenation of lipid body membranes is promoted by a patatin-type phospholipase in cucumber cotyledons. $J$ Exp Bot. 2011; 62(2): 749-760.

6. Vidhyasekaran P. Plant hormone signaling systems in plant innate immunity. Dordrecht: Springer, 2015. $200 \mathrm{p}$.

7. Osterman LA. Chromatography of proteins and nucleic acids. M.: Science, 1985. 535 p.

8. Kochetov GA. A practical manual to enzymology. M.: Vysshaya shkola, 1980. 271 p. 
9. Dubtsov GG, Popov MP. Method of wheat lipoxygenase determination. Prikl Biokhim Mikrobiol. 1970; 6(4): 471-475.

10. Lowry OH, Rosebrough NJ, Farr AL, Randall RJ. Protein measurement with the Folin phenol reagent. J Biol Chem. 1951; 193(1): 265-275.

11. Borisova IG, Gordeeva NT, Budnytskaya EV. Comparative research of molecular forms composition of plant lipoxygenases. Dokl Akad Nauk SSSR. 1981; 261(5): 1260-1263.

12. Chen G, Hackett R, Walker D, Taylor A, Lin Z, Grierson D. Identification of a specific isoform of tomato lipoxygenase (TomloxC) involved in the generation of fatty acid-derived flavor compounds. Plant Physiol. 2004; 136(1): 26412651.
13. Hale SA, Richardson T, von Elbe JH, Hagedorn DJ. Lipids 4. 1969: 209-215.

14. Shiiba K, Negishi Y, Okada K, Nagao S. Purification and characterization of lipoxygenase isoformes from wheat germ. Cereal Chem. 1991; 68(2): 115-122.

15. Adamovskaya VG, Klechkovskaya EA, Molodchenkova OO, Vovchuck SV. The change of proteinase-inhibitor system of winter wheat at the action of salicylic acid and Fusarium. Plant Physiol. 2000; 47(2): 210-215.

Received 26.07.2016 